\title{
57. ACOUSTIC PROPERTIES OF LIMESTONES FROM THE NORTH-CENTRAL PACIFIC, DEEP SEA DRILLING PROJECT LEG 62 ${ }^{1}$
}

\author{
R. L. Carlson, Department of Geophysics and Geodynamics, Research Program, Texas A\&M University, \\ College Station, Texas
}

\section{INTRODUCTION}

Variations of acoustic properties within the sediment column may significantly affect the propagation of acoustic energy in the upper portion of the oceanic crust. Moreover, the acoustic properties of sediments reflect their mineral compositions, fabrics, and degrees of compaction and cementation. Hence, the physical properties of indurated deep-sea sediments are of considerable geophysical and geological interest. Chalks and limestones are particularly important because substantial accumulations of biogenic carbonates are generally present at the base of the deep-sea sediment column, and high-standing features such as Hess Rise are capped by calcareous deposits.

This paper constitutes a preliminary report of the compressional-wave velocities and densities of 31 indurated calcareous sediment samples recovered at DSDP Sites 463 and 465, in the Mid-Pacific Mountains and on Hess Rise, respectively. The sample set includes nine pairs of samples in which velocities were measured parallel and perpendicular to bedding to determine the velocity anisotropy of the sediment. This research is part of an ongoing study of the seismic properties of indurated deep-sea carbonates.

\section{PROCEDURES}

A number of samples were collected aboard the Glomar Challenger and shipped directly to the shore laboratory; others were carefully selected from the DSDP archives at Scripps Institution of Oceanography in December 1978. The samples were prepared for the velocity and density measurements by first cutting mini-cores 1.27 , 1.91 , or $2.54 \mathrm{~cm}$ in diameter with axes parallel or perpendicular to the drill-core axis. The ends of the mini-cores were trimmed to form rightcircular cylinders 1.7 to $3.4 \mathrm{~cm}$ long. Because water saturation is known to affect acoustic velocities in porous media (e.g., Wyllie et al., 1958), the samples were brought to full saturation by soaking in water for approximately two weeks. Thereafter, the water-saturated condition of the samples was carefully maintained.

Wet-bulk densities were independently determined with a Jolly balance and from the weights and computed volumes of the cylinders. The results generally agree to within $1 \%$, with a maximum difference of $2 \%$. Because the sediments are relatively soft materials, coring frequently produces slight irregularities such as grooves or chips in the cylinders, which affect the accuracies of computed sample volumes and computed densities. Consequently, the Jolly-balance values are thought to be most accurate.

The samples were prepared for velocity measurements at elevated pressures by wrapping the cylinders in 100-mesh copper screen and a copper-foil jacket. The screen provides voids into which pore water

\footnotetext{
${ }^{1}$ Intial Reports of the Deep Sea Drilling Project, Volume 62.
}

from the sample can escape, thereby minimizing pore pressures at elevated confining pressures. The copper jacket prevents the pressure medium from entering the rock. Compressional-wave velocities were measured by the pulse-transmission method as described by Birch (1960), at hydrostatic confining pressure to $0.6 \mathrm{kbar}$, using $1-\mathrm{MHz}$ lead-zirconate-titanate (PZT-5) transducers. Density and velocity data are summarized in Table 1.

\section{VELOCITY-DENSITY RELATIONS}

Velocity-density relations for the calcareous sediments recovered on Leg 62 are illustrated in Figure 1. Included for comparison are data for a variety of previously studied deep-sea basalts and carbonates (Christensen and Salisbury, 1972, 1973; Christensen, 1973a,b; Christensen et al., 1973, 1974a,b; Carlson and Christensen, 1977a,b, 1979; Carlson in press).

For the Leg 62 samples, wet-bulk densities range from 2.00 to $2.54 \mathrm{~g} / \mathrm{cm}^{3}$, and corresponding compressional-wave velocities measured at $0.2 \mathrm{kbar}$ range from 2.60 to $5.15 \mathrm{~km} / \mathrm{s}$. The most striking feature of Figure 1 is the range of velocities observed in calcareous sediments of similar density. The carbonates having the lowest velocities are those recovered from the floor of the western South Atlantic on DSDP Leg 39. Their properties have been discussed in detail by Carlson and Christensen (1979), and their velocity-density trend closely approximates the relation predicted by Hamilton (1978). The carbonate samples from Leg 62 have velocities about $0.7 \mathrm{~km} / \mathrm{s}$ higher than those of samples from Leg 39 having similar densities.

The fundamental difference between the Leg 39 and Leg 62 carbonates which gives rise to this striking difference in their physical properties is difficult to quantify. It is not related to age or depth of burial, but the Leg 62 sediments are harder and more brittle than the chalks from Leg 39 , suggesting that those recovered on Leg 62 are more highly cemented. Furthermore, Dean (this volume) has found that the calcareous rocks from Site 463 are highly silicified, with silica contents ranging up to $50 \%$. Silica content was also found to be highly variable, and this may account for the marked differences in density between samples from adjacent portions of the drill core, and for the high velocities of these sediments. Unfortunately, these materials are generally so fine-grained that thin-section analysis is of little use in resolving this problem and other factors, such as degree of recrystallization, or clay and organic content, have not yet been assessed. 
Table 1. Summary of acoustic properties.

\begin{tabular}{|c|c|c|c|c|c|c|c|c|c|c|}
\hline \multirow{2}{*}{$\begin{array}{c}\text { Sample } \\
\text { (interval in } \mathrm{cm} \text { ) }\end{array}$} & \multirow{2}{*}{$\begin{array}{l}\text { Depth of } \\
\text { Recovery } \\
\text { (m) }\end{array}$} & \multirow{2}{*}{$\begin{array}{l}\text { Propagation } \\
\text { Direction }\end{array}$} & \multirow{2}{*}{$\begin{array}{l}\text { Wet-Bulk } \\
\text { Density } \\
\left(\mathrm{g} / \mathrm{cm}^{3}\right)\end{array}$} & \multicolumn{6}{|c|}{$\begin{array}{l}\text { Compressional-Wave Velocity (km/s) vs. } \\
\text { Pressure (kbar) }\end{array}$} & \multirow[b]{2}{*}{ Lithology } \\
\hline & & & & 0.1 & 0.2 & 0.3 & 0.4 & 0.5 & 0.6 & \\
\hline $463-56-1,102-107$ & 491 & $v$ & 2.14 & 2.89 & 2.96 & 2.98 & 2.99 & - & - & Nannofossil chalk \\
\hline $58-2,53-57$ & 511 & v & 2.33 & 3.64 & 3.69 & 3.73 & 3.76 & 3.78 & 3.80 & $\begin{array}{l}\text { Nannofossil } \\
\text { limestone }\end{array}$ \\
\hline $59-2,29-34$ & 520 & $v$ & 2.10 & 2.61 & 2.67 & 2.70 & 2.72 & 2.73 & 2.74 & $\begin{array}{l}\text { Nannofossil } \\
\text { limestone }\end{array}$ \\
\hline $60-1,101-103$ & 529 & $v$ & 2.34 & 3.41 & 3.47 & 3.46 & 3.54 & 3.56 & 3.58 & $\begin{array}{l}\text { Nannofossil- } \\
\text { foraminifer } \\
\text { limestone }\end{array}$ \\
\hline \multirow[t]{3}{*}{$60-4,38-43$} & 533 & $\mathrm{~h}$ & 2.34 & 3.19 & 3.24 & 3.28 & 3.32 & 3.34 & 3.35 & Nannofossil- \\
\hline & & v & 2.39 & 3.10 & 3.14 & 3.17 & - & - & - & foraminifer \\
\hline & & mean & 2.36 & 3.15 & 3.19 & 3.23 & - & -7 & - & limestone \\
\hline $60-4,110-112$ & 534 & h & 2.37 & 3.65 & 3.70 & 3.73 & 3.76 & 3.78 & 3.79 & $\begin{array}{l}\text { Nannofossil- } \\
\text { foraminifer } \\
\text { limestone }\end{array}$ \\
\hline $62-3,35-41$ & 541 & h & 2.35 & 3.83 & 3.88 & 3.92 & 3.95 & 3.97 & 3.98 & Limestone \\
\hline \multirow[t]{3}{*}{$62-3,97-102$} & 541 & $\mathrm{~h}$ & 2.17 & 3.13 & 3.21 & 3.25 & 3.28 & 3.30 & 3.31 & Limestone \\
\hline & & v & 2.22 & 3.37 & 3.42 & 3.45 & 3.48 & 3.50 & 3.51 & \\
\hline & & mean & 2.20 & 3.25 & 3.31 & 3.35 & 3.38 & 3.40 & 3.41 & \\
\hline \multirow[t]{3}{*}{$65-1,14-19$} & 566 & h & 2.32 & 3.60 & 3.66 & 3.70 & 3.73 & 3.74 & 3.76 & Nannofossil \\
\hline & & v & 2.22 & 3.12 & 3.21 & 3.27 & 3.31 & 3.33 & 3.34 & limestone \\
\hline & & mean & 2.27 & 3.36 & 3.44 & 3.49 & 3.52 & 3.54 & 3.55 & \\
\hline $67-2,135-140$ & 588 & h & 2.24 & 3.08 & 3.16 & 3.20 & 3.30 & - & - & $\begin{array}{l}\text { Nannofossil } \\
\text { limestone }\end{array}$ \\
\hline \multirow[t]{3}{*}{$70-3,16-22$} & 617 & $\mathrm{~h}$ & 2.13 & 3.22 & 3.26 & 3.28 & 3.30 & 3.31 & 3.31 & Ashy limestone \\
\hline & & $\mathbf{v}$ & 2.10 & 2.86 & 2.92 & 2.95 & 2.97 & 2.98 & 2.99 & \\
\hline & & mean & 2.12 & 3.04 & 3.09 & 3.12 & 3.14 & 3.15 & 3.15 & \\
\hline $71-3,100-106$ & 627 & h & 2.00 & 2.57 & 2.60 & 2.63 & 2.65 & 2.67 & 2.68 & Ashy limestone \\
\hline $72-2,58-64$ & 635 & $\mathrm{~h}$ & 2.15 & 3.27 & 3.30 & 3.31 & 3.32 & 3.33 & - & Limestone \\
\hline \multirow[t]{3}{*}{$72-2,142-150$} & 636 & $\mathrm{~h}$ & 2.11 & 3.22 & 3.27 & 3.30 & 3.32 & 3.34 & 3.35 & Limestone \\
\hline & & v & 2.10 & 2.96 & 3.01 & 3.04 & 3.06 & 3.07 & 3.08 & \\
\hline & & mean & 2.11 & 3.09 & 3.14 & 3.17 & 3.19 & 3.21 & 3.22 & \\
\hline $73-1,52-58$ & 643 & h & 2.07 & 2.84 & 2.88 & 2.90 & 2.92 & 2.94 & 2.95 & Limestone \\
\hline \multirow[t]{3}{*}{$73-1,60-65$} & 643 & $\mathrm{~h}$ & 2.09 & 3.21 & 3.22 & 3.33 & 3.35 & 3.36 & 3.37 & Limestone \\
\hline & & v & 2.08 & 3.01 & 3.03 & 3.04 & 3.05 & 3.06 & 3.07 & \\
\hline & & mean & 2.09 & 3.11 & 3.13 & 3.19 & 3.20 & 3.21 & 3.22 & \\
\hline $80-1,15-20$ & 709 & $\mathrm{v}$ & 2.53 & 3.89 & 4.04 & 4.16 & 4.25 & 4.32 & 4.37 & Limestone breccia \\
\hline $83-2,3-7$ & 729 & $\mathrm{v}$ & 2.52 & 4.88 & 4.91 & 4.94 & 4.96 & 4.97 & 4.99 & Limestone \\
\hline $84-1,84-89$ & 738 & $\mathrm{~h}$ & 2.44 & 4.51 & 4.55 & 4.58 & 4.60 & 4.63 & 4.64 & Clastic limestone \\
\hline $85-2,105-110$ & 749 & $\mathrm{~h}$ & 2.47 & 4.45 & 4.49 & 5.52 & 5.54 & 5.56 & 5.57 & $\begin{array}{l}\text { Clastic limestone } \\
\text { (mainly oolites) }\end{array}$ \\
\hline \multirow[t]{3}{*}{$465 \mathrm{~A}-27-2,37-45$} & 288 & h & 1.54 & 5.09 & 5.15 & 5.18 & 5.20 & 5.22 & - & Limestone \\
\hline & & v & 2.49 & 4.46 & 4.52 & 4.56 & 4.59 & 4.61 & 4.63 & \\
\hline & & mean & 2.52 & 4.78 & 4.84 & 4.87 & 4.90 & 4.92 & - & \\
\hline \multirow[t]{3}{*}{$33-1,48-54$} & 343 & h & 2.32 & 3.91 & 3.96 & 4.00 & 4.03 & 4.05 & 4.07 & Limestone \\
\hline & & v & 2.24 & 3.10 & 3.18 & 3.24 & 3.29 & 3.33 & 3.35 & \\
\hline & & mean & 2.28 & 3.51 & 3.57 & 3.62 & 3.66 & 3.69 & 3.71 & \\
\hline
\end{tabular}

\section{ANISOTROPY}

Velocity anisotropy significantly affects the propagation of seismic waves. Deep-sea sediments are generally found to be anisotropic (e.g., Boyce, 1976; Tucholke et al., 1976; Carlson and Christensen, 1977b), with velocities parallel to bedding $\left(V_{\mathrm{h}}\right)$ exceeding velocities normal to bedding $\left(V_{\mathrm{v}}\right)$. Having studied samples recovered on DSDP Leg 39, Carlson and Christensen (1979) suggested that in chalks and limestones the phenomenon results from the preferred orientation of calcite grains, rather than the alignment of cracks and pores in the sediment.

In measuring anisotropy, one would prefer to measure velocities in several directions in the same sample. Unfortunately, deep-sea sediment samples are notoriously difficult to work with. The principal difficulty is preventing the pressure medium from entering the rock. This problem is compounded by the necessity of using screens to maintain low pore pressures. At present, the use of cylindrical samples jacketed in copper foil is the only reliable means of isolating the sediments from the pressure medium. The technique has the disadvantage that it requires separate samples for measurement of velocity in different directions. When the samples have different densities, the measured differences between horizontal and vertical velocities reflect the dependence of velocity on bulk density as well as the anisotropic nature of the material, as evidenced in Figure 1.

It is worth noting that the horizontally oriented samples have higher densities than corresponding vertically oriented samples in seven of eight cases, so that the density differences at first appear to be systematic. However, in three cases the difference in sample densities is within the error of the measurements. The horizontal samples have significantly higher densities in only four of six cases. This distribution is not unlikely in a random sampling of the sediment.

A purely arbitrary means of assessing the degree of anisotropy in samples of different density is to establish the relation between velocity and density and then ad- 


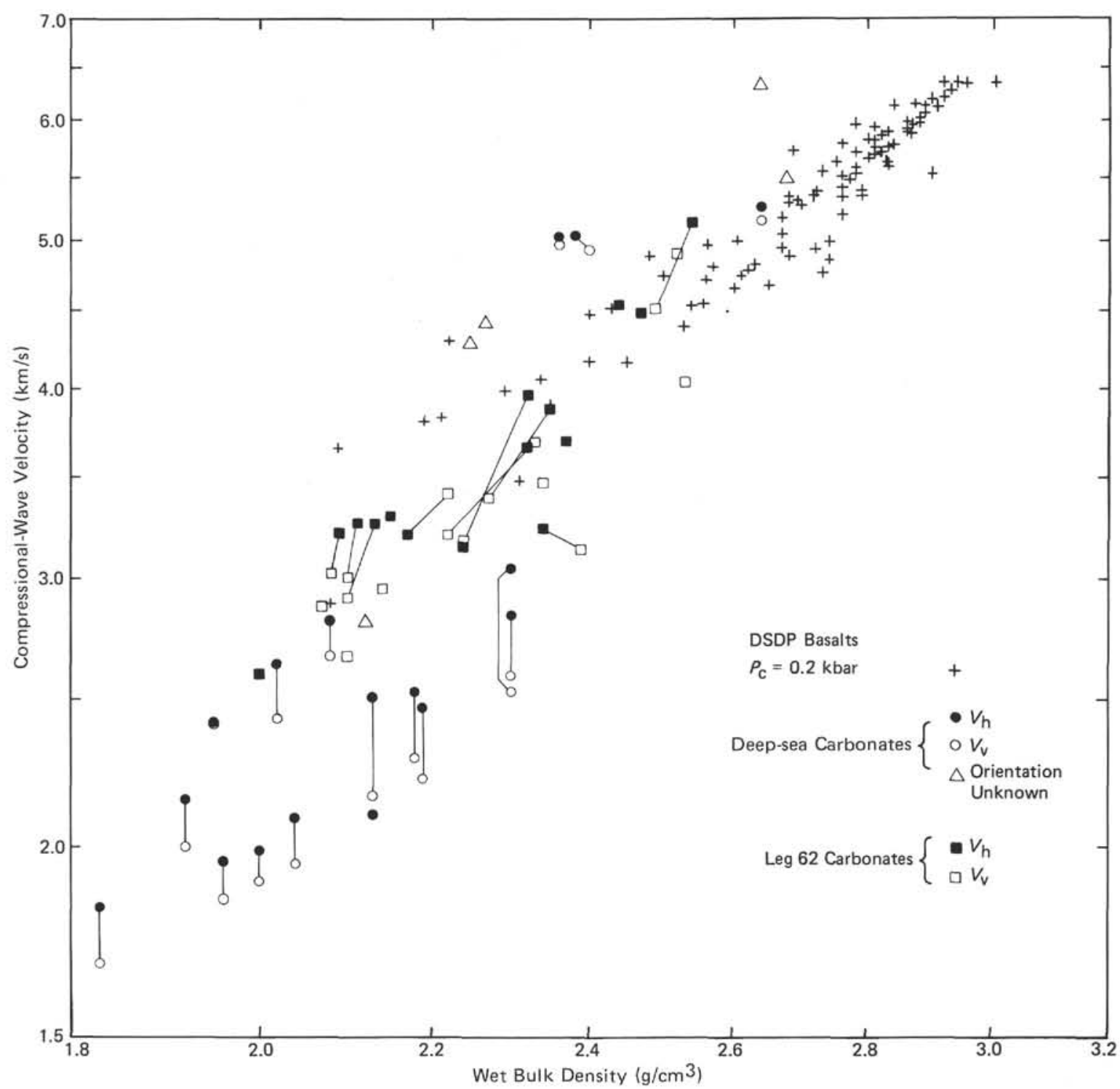

Figure 1. Compressional-wave velocity versus wet-bulk density for deep-sea carbonates and basalts. Lines connect data for pairs of samples in which velocities were measured parallel and perpendicular to bedding. See text for sources of data from previous studies.

just the velocities accordingly. To this end, the horizontal- and vertical-velocity data for the Leg 62 carbonates (Table 1) were independently used to establish the regression parameters of the linear relation

$$
\ln V=\ln A+B(\ln \varrho) \text {. }
$$

The procedure assumes that velocity and density are related by the power law

$$
V=A \varrho^{B}
$$

where $A$ and $B$ are constants. Data for Sample 463-60-4, $38-43 \mathrm{~cm}$, a nannofossil-foraminifer limestone, fall well off the general trend for Leg 62 samples and were not included in the analysis. The regression parameters are summarized in Table 2. On the assumption that both samples exhibit the same degree of velocity anisotropy, the vertical velocities were corrected for the difference in the densities of the samples:

$$
\ln V_{\mathrm{v}}^{\prime}=\ln V_{\mathrm{v}}+2.29\left(\ln \varrho_{\mathrm{h}}-\ln \varrho_{\mathrm{v}}\right)
$$

where $\varrho_{\mathrm{h}}$ and $\varrho_{\mathrm{y}}$ are the densities of the horizontally and vertically oriented cylindrical samples. This procedure amounts to estimating the vertical velocity in the horizontally oriented sample. The results are summarized in Table 3 and illustrated in Figure 2, where horizontal and corrected vertical velocities are plotted against the densities of the horizontal samples. Again, results from previous studies are included for comparison.

The laminated limestones from Site 463 have estimated anisotropy coefficients $\left(V_{\mathrm{h}} / V_{\mathrm{v}}\right)$ ranging from 1.03 to 1.08 , in general agreement with the results of previous studies. The limestones from Site 465 , on Hess Rise, were recovered from sub-bottom depths less than 
Table 2. Linear-regression parameters: $\ln V=\ln A+B(\ln \varrho)$.

\begin{tabular}{ccccc}
\hline & $A$ & $B$ & $N$ & $r$ \\
\hline$V_{\mathrm{h}}$ & 0.52 & 2.39 & 14 & 0.94 \\
$V_{\mathrm{V}}$ & 0.53 & 2.29 & 15 & 0.94 \\
\hline
\end{tabular}

Note: $N=$ number of samples; $r=$ correlation coefficient
Table 3. Anisotropy data $\left(P_{\mathrm{c}}=0.2 \mathrm{kbar}\right)$.

\begin{tabular}{cccrc}
\hline $\begin{array}{c}\text { Sample } \\
\text { (interval in } \mathrm{cm})\end{array}$ & $\begin{array}{c}V_{\mathrm{h}} \\
(\mathrm{km} / \mathrm{s})\end{array}$ & $\begin{array}{c}V_{\mathrm{v}}^{\prime} \\
(\mathrm{km} / \mathrm{s})\end{array}$ & $\begin{array}{c}\Delta V \\
(\mathrm{~km} / \mathrm{s})\end{array}$ & $a$ \\
\hline $463-60-4,38-43$ & 3.24 & 2.99 & 0.25 & 1.08 \\
$62-3,35-41$ & 3.88 & 3.67 & 0.21 & 1.06 \\
$62-3,97-102$ & 3.21 & 3.25 & -0.04 & 0.99 \\
$65-1,14-19$ & 3.66 & 3.55 & 0.11 & 1.03 \\
$70-3,16-22$ & 3.26 & 3.02 & 0.24 & 1.08 \\
$72-2,142-150$ & 3.27 & 3.04 & 0.23 & 1.08 \\
$73-1,60-65$ & 3.22 & 3.06 & 0.16 & 1.05 \\
$465 \mathrm{~A}-27-2,37-45$ & 5.15 & 4.73 & 0.42 & 1.09 \\
$33-1,48-54$ & 3.96 & 3.45 & 0.51 & 1.15 \\
\hline
\end{tabular}

Note: $V_{\mathrm{v}}^{\prime}$ is corrected vertical velocity; $a=V_{\mathrm{h}} / V_{\mathrm{v}}^{\prime}$

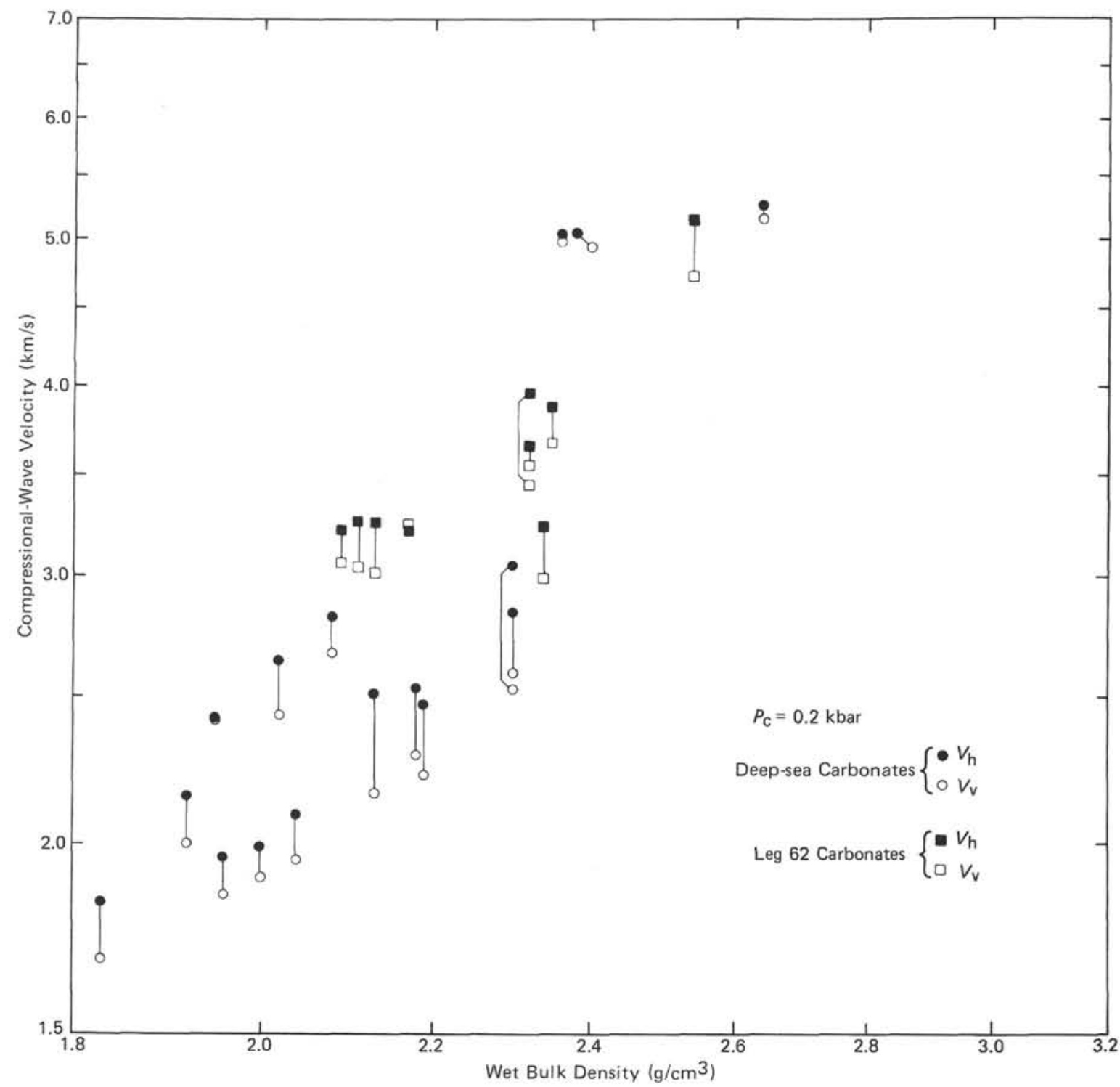

Figure 2. Compressional-wave velocity versus wet-bulk density for deep-sea carbonates. Lines connect data for pairs of samples in which velocities were measured parallel and perpendicular to bedding. Vertical velocities of Leg 62 samples have been adjusted to the densities of samples in which $V_{\mathrm{h}}$ was measured, to show estimated velocity anisotropy. See text. 
350 meters, and are substantially more anisotropic than previously studied carbonates recovered from similar depths in the sediment column (e.g., Carlson and Christensen, 1979). These results confirm that depth of burial is not the only important parameter which influences the development of velocity anisotropy in calcareous deep-sea sediments, and they underscore the variability of acoustic properties of the sediment column in different localities.

\section{VELOCITY-DEPTH RELATIONS AT SITE 465}

In addition to their high degree of velocity anisotropy, the limestones from Hole 465A have relatively high compressional-wave velocities (Table 1). Christen- sen et al. (this volume) have studied the seismic properties of one volcanic breccia and four highly-altered, vesicular, trachytic rocks recovered at this site. Velocity-depth relations are shown in Figure 3. The igneous rocks have velocities between 3 and $4 \mathrm{~km} / \mathrm{s}$, whereas the limestones show a maximum velocity greater than 5 $\mathrm{km} / \mathrm{s}$. The marked negative velocity-depth gradient in the limestone section, although it is based on only two data points, is in excellent agreement with data from shipboard velocity measurements (Site 465 report, this volume). The high sediment velocities above lowervelocity basement rocks indicate that a significant lowvelocity zone of unknown vertical extent exists in the vicinity of Site 465 .

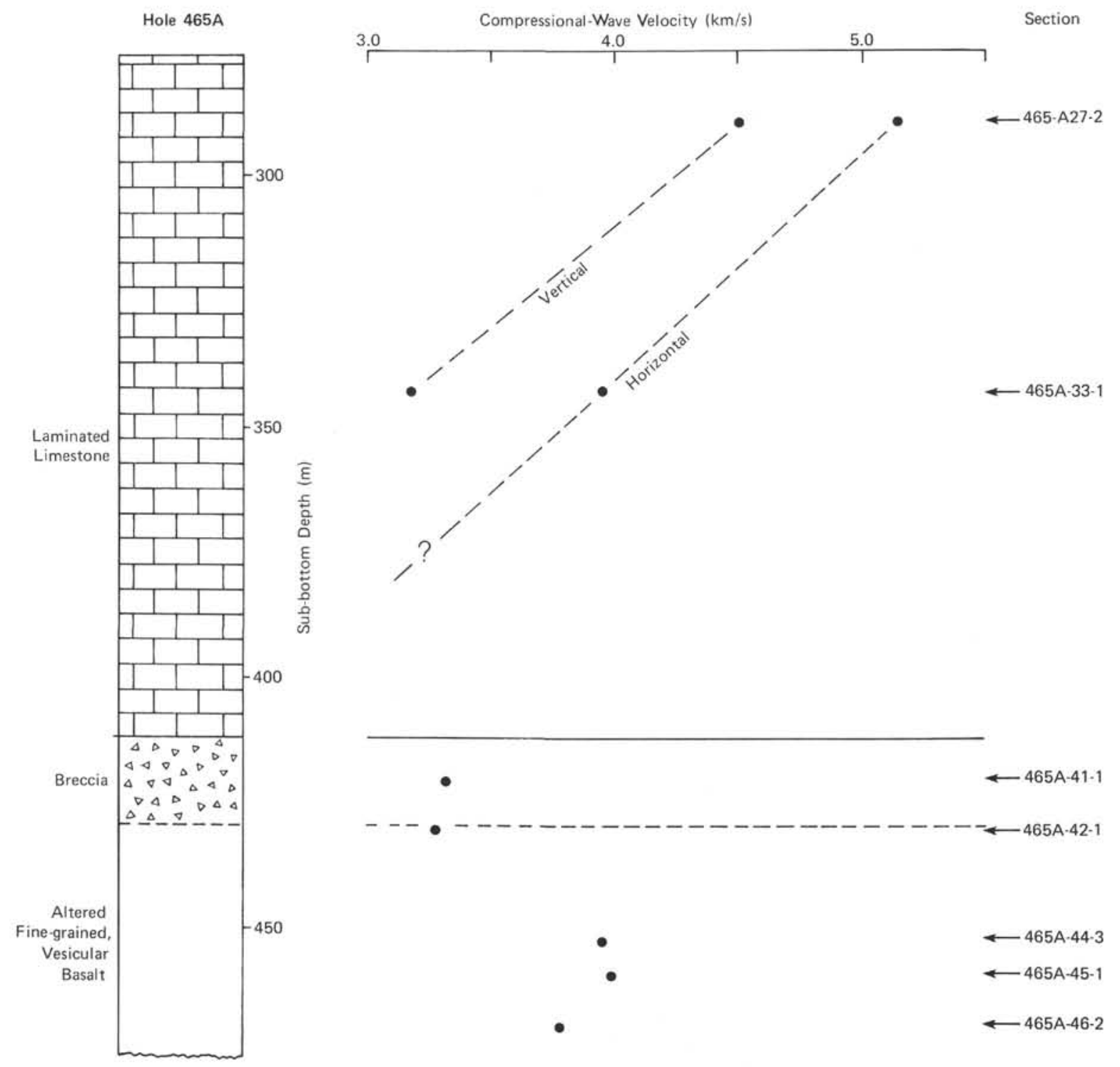

Figure 3. Compressional-wave velocity at $P_{\mathrm{c}}=0.2$ kbar versus depth of recovery, Hole 465A. 


\section{ACKNOWLEDGMENTS}

I wish to thank N. I. Christensen and R. B. Scott for their many helpful suggestions and for reviewing the manuscript. I also wish to thank Dr. Christensen for the use of his laboratory facilities at the University of Washington. J. Schultz maintained the high-pressure system. This project was supported by NSF Grant OCN-7817919.

\section{REFERENCES}

Birch, R., 1960. The velocity of compressional waves in rocks, part 1 . J. Geophys. Res., 65:1083-1102.

Boyce, R. E., 1976. Sound velocity-density parameters of sediments and rocks from DSDP Sites 315-318 on the Line Islands, Manihiki Plateau, and Tuamotu Ridge in the Pacific Ocean. In Schlanger, S. O., Jackson, E. D., et al., Init. Repts. DSDP, 33: Washington (U.S. Govt. Printing Office), 695-728.

Carlson, R. L., in press. Acoustic properties of tuffaceous and calcareous sediments, DSDP Leg 60. In Hussong, D., Uyeda, S., et al., Init. Repts. DSDP, 60: Washington (U.S. Govt. Printing Office).

Carlson, R. L., and Christensen, N. I., 1977a. Velocities, densities and elastic constants of basalt and trachytic tuff, DSDP Leg 39. In Supko, P. R., Perch-Nielsen, K., et al., Init. Repts. DSDP, 39: Washington (U.S. Govt. Printing Office), 493-495. 1977b. Velocity anisotropy and physical properties of deepsea sediments from the western South Atlantic. In Supko, P. R., Perch-Nielsen, K., et al., Init. Repts. DSDP, 39: Washington (U.S. Govt. Printing office), 555-559.

, 1979. Velocity anisotropy in semi-indurated calcareous deep sea sediments. J. Geophys. Res., 84:205-211.

Christensen, N. I., 1973a. Compressional and shear velocities in basaltic rocks, Deep Sea Drilling Project, Leg 16. In van Andel, Tj. H., Heath, G. R., et al., Init. Repts. DSDP, 16: Washington (U.S. Govt. Printing Office), 647-649. 1973b. Compressional and shear velocities and elastic moduli of basalts, Deep Sea Drilling Project, Leg 19. In Creager, J. S., Scholl, D. W., et al., Init. Repts. DSDP, 19: Washington (U.S. Govt. Printing Office), 657-659.

Christensen, N. I., Fountain, D. M., Carlson, R. L., et al., 1974a. Velocities and elastic moduli of volcanic and sedimentary rocks recovered on DSDP Leg 25. In Simpson, E. S. W., Schlich, R., et al., Init. Repts. DSDP, 25: Washington (U.S. Govt. Printing Office), 357-360.

Christensen, N. I., Fountain, D. M., and Steward, R. J., 1973. Oceanic crustal basement: a comparison of seismic properties of DSDP basalts and consolidated sediments. Mar. Geol., 15:215226.

Christensen, N. I., and Salisbury, M. H., 1972. Sea floor spreading, progressive alteration of layer 2 basalts, and associated changes in seismic velocities. Earth Planet. Sci. Lett., 15:367-375.

1973. Velocities, elastic moduli and weathering-age relations for Pacific layer 2 basalts. Earth Planet. Sci. Lett., 19:461-470.

Christensen, N. I., Salisbury, M. H., Fountain, D. M., et al., 1974b. Velocities of compressional and shear waves in DSDP Leg 27 basalts. In Veevers, J. J., Heirtzler, J. R., et al., Init. Repts. DSDP, 27: Washington (U.S. Govt. Printing office), 445-559.

Hamilton, E. L., 1978. Sound velocity-density relations in sea-floor sediments and rocks. J. Acoustical Soc. Am., 63:366-377.

Tucholke, B. E., Edgar, N. T., and Boyce, R. E., 1976. Physical properties of sediments and correlations with acoustic stratigraphy: Leg 35. In Hollister, D. C., Craddock, C., et al., Init. Repts. DSDP, 35: Washington (U.S. Govt. Printing office), 229-250.

Wyllie, M. R. J., Gregory, A. R., and Gardner, G. H. F., 1958. An experimental investigation of factors affecting elastic wave velocities in porous media. Geophysics, 23:459-493. 